\title{
ANALISIS KETERKAITAN ANTARA KEKERINGAN METEOROLOGIS DENGAN INDEKS VEGETASI TERSTANDARISASI DI PULAU LOMBOK
}

\author{
Analysis of Relationship Between Meteorological Drought and \\ Standardized Vegetation Index on Lombok Island
}

\author{
Siti Najma Nindya Utami ${ }^{1}{ }^{\star}$, Rista Hernandi Virgianto'), Dzikrullah Akbar ${ }^{2)}$ \\ 1) Stasiun Pemantau Atmosfer Global, Badan Meteorologi Klimatologi dan Geofisika, Jalan Sungai \\ Remu KM.8 Malanu, Kelurahan Malaingkedi, Sorong, Papua Barat 98412 \\ 2) Sekolah Tinggi Meteorologi Klimatologi dan Geofisika, Jalan Perhubungan I No.5, Pondok Betung, \\ Pondok Aren, Tangerang Selatan, Banten 15221 \\ email: nindyutamy@gmail.com
}

\begin{abstract}
Intisari
Kekeringan merupakan bencana kompleks yang dapat menyebabkan kerugian masyarakat di berbagai sektor. Salah satu wilayah yang berisiko tinggi mengalami kekeringan adalah Pulau Lombok. Wilayah ini memiliki lahan yang berisiko terkena kekeringan seluas 405.985 ha. Tingkat keparahan kekeringan meteorologis dapat diukur dengan Standardized Precipitation Evapotranspiration Index (SPEI). Salah satu karakteristik kekeringan adalah kondisi vegetasi tanaman yang buruk, oleh karena itu Standardized Vegetation Index (SVI) digunakan sebagai acuan dalam monitoring kekeringan agrikultural. Penelitian ini bertujuan untuk mengetahui hubungan antara SPEI dengan SVI untuk setiap pos hujan di Pulau Lombok tahun 2001-2018. Penelitian ini menggunakan data bulanan tahun 2001-2018 yang meliputi data observasi curah hujan, suhu maksimum, suhu minimum, penginderaan jauh Normalized Differences Vegetation Index (NDVI) dengan resolusi $0,05^{\circ}$, model FLDAS kecepatan angin yang juga didapatkan dengan resolusi $0,5^{\circ}$, lama penyinaran matahari, lintang, dan elevasi. Metode yang digunakan yaitu menghitung indeks kekeringan SPEI dan SVI, kemudian menghitung korelasi dan signifikansi untuk kedua indeks kekeringan tersebut. Hasilnya menunjukkan bahwa SPEI lebih tinggi berkorelasi dengan SVI +1 dengan kategori cukup kuat. Untuk SPEI, SPEI6, dan SPEl 12 berkorelasi cukup kuat hingga kuat dengan SVIo. Hal ini menunjukkan bahwa kekeringan jangka panjang akan langsung mempengaruhi kekeringan agrikultural atau kekeringan vegetasi saat itu juga. Nilai korelasi yang lebih tinggi untuk setiap indeks tersebar di pos hujan yang terletak di tengah-tengah Pulau Lombok, karena pengaruh kondisi geografis dan demografis
\end{abstract}

Kata Kunci: Kekeringan Meteorologis, Kekeringan Agrikultural, SPEI, SVI

\begin{abstract}
Drought is a complex disaster because it can cause loss to society in various sectors. One of the high-risk areas of drought is Lombok Island. This area has 405,985 ha of drought risk. The severity of meteorological drought can be measured by the Standardized Precipitation Evapotranspiration Index (SPEI). One of the characteristics of drought is the poor condition of plant vegetation, therefore the Standardized Vegetation Index (SVI) is used as a reference in monitoring agricultural drought. This study aims to determine the relationship of SPEI with SVI for each rainfall post in Lombok Island from 2001-2018. This study uses monthly data from 2001-2018, including observation data of rainfall, maximum temperature, minimum temperature, remote sensing Normalized Differences Vegetation Index (NDVI) $0.05^{\circ}$, FLDAS model of wind speed $0.5^{\circ}$, length of the day, latitude, and elevation. The use method is to calculate SPEI and SVI, then calculate the correlation and significance for the two drought indices. The result shows that SPEI1 is higher in correlation with SVI+1, which is in a strong enough category. For SPEI3, SPEI6, and SPEI12, the correlation is strong enough to strong with SVIO. This suggests that long-term drought will directly affect agricultural drought or immediate vegetation drought. The higher correlation values for each index are spread over the rain posts located in the middle of Lombok Island because geographic and demographic conditions influence them.
\end{abstract}

Keywords: Meteorological Drought, Agricultural Drought, SPEI, SVI 


\section{PENDAHULUAN}

Kekeringan merupakan bencana alam yang kompleks dan menyebabkan kerugian di berbagai sektor kehidupan (Wilhite dan Glantz 1985; Wilhite 1993), seperti memberi dampak pada lingkungan dan sosial ekonomi, termasuk pertanian, produksi energi, suplai air untuk masyarakat, serta kualitas air. Penyebab utama terjadinya kekeringan adalah defisit curah hujan yang terjadi selama periode tertentu sehingga tidak dapat memenuhi kebutuhan manusia, atau yang biasanya disebut dengan kekeringan meteorologis. Kekeringan akibat defisit curah hujan dapat berdampak pada kekeringan pertanian (vegetasi), namun ada lag (jarak waktu) di antara keduanya. Sehingga kekeringan meteorologis dapat menjadi indikator awal terjadinya kekeringan agrikultural (pertanian).

$$
\text { Dalam kajian Badan Nasional }
$$

Penanggulangan Bencana (2015) yang selanjutnya disebut BNPB, menyatakan bahwa kekeringan menjadi bencana kedua yang sering terjadi di wilayah Nusa Tenggara Barat (NTB), dengan banyaknya kejadian sebesar 96 kali atau setara dengan $25,46 \%$ dari total keseluruhan kejadian bencana alam periode 1885-2015. Hal ini menyebabkan wilayah NTB termasuk Lombok, memiliki klasifikasi kekeringan dengan kategori tinggi dalam tingkat risiko, kerentanan, dan frekuensi kejadiannya.

Salah satu indeks yang digunakan untuk monitoring kekeringan meteorologis adalah Standardized Precipitation Evapotranspiration Index (SPEI) (Vicente-Serrano et al., 2010a). Selain menggunakan parameter curah hujan, indeks ini juga menggunakan parameter evapotranspirasi sehingga dianggap lebih detail dalam mengkaji kondisi kekeringan di suaru wilayah. Standardized Vegetation Index (SVI) (Peters et al., 2002) atau indeks vegetasi lahan adalah indeks kekeringan yang menjadikan kondisi vegetasi lahan berbasis pengindraan jauh sebagai parameter utamanya. Penggunaan SVI ini berdasarkan pada penelitian yang telah dilakukan oleh Maina (2018), Park, et al. (2008), dan Qi, et al. (2004) yang memberikan gambaran jika SVI dapat dijadikan salah satu indeks dalam penentuan tingkat kekeringan agrikultural di suatu wilayah dibandingkan dengan indeks kekeringan meteorologis, yang dalam penelitian ini menggunakan SPEI. Indeks kekeringan meteorologis (SPEI) dapat dijadikan parameter untuk mengidentifikasi dan mendeteksi kekeringan pertanian di wilayah Cina Timur dengan korelasi rata-rata sebesar 0,48 (Zuo, et al., 2019) dan di Maroko, Afrika Utara deng korelasi rata-rata sebesar 0,55 (Ezzine, et al., 2014).

Penelitian ini bertujuan untuk mengetahui hubungan antara kekeringan meteorologis (SPEI) dengan kekeringan agrikultural (pertanian) yang diwakili oleh SVI di Pulau Lombok tahun 20012018. Manfaat penelitian ini adalah untuk menambah pengetahuan sejauh mana kekeringan meteorologis mempengaruhi kondisi agrikultural di wilayah Lombok dan menjadi bahan pertimbangan untuk monitoring kekeringan di lingkup BMKG. Selain itu, sebagai sumbangsih bagi perkembangan ilmu pengetahuan meteorologi dan klimatologi pada umumnya, serta untuk perkembangan BMKG pada khususnya.

\section{METODE}

Lokasi yang menjadi objek penelitian adalah 22 titik pos hujan Pulau Lombok di Provinsi Nusa Tenggara Barat yang secara astronomis terletak antara $8,15^{\circ}-8,60^{\circ}$ LS dan $115,85^{\circ}$ $116,45^{\circ}$ BT. Pemilihan 22 titik pos hujan berdasarkan kelengkapan data 100\%. Sebaran pos hujan yang digunakan dalam penelitian ini secara detail disajikan dalam Gambar 1.

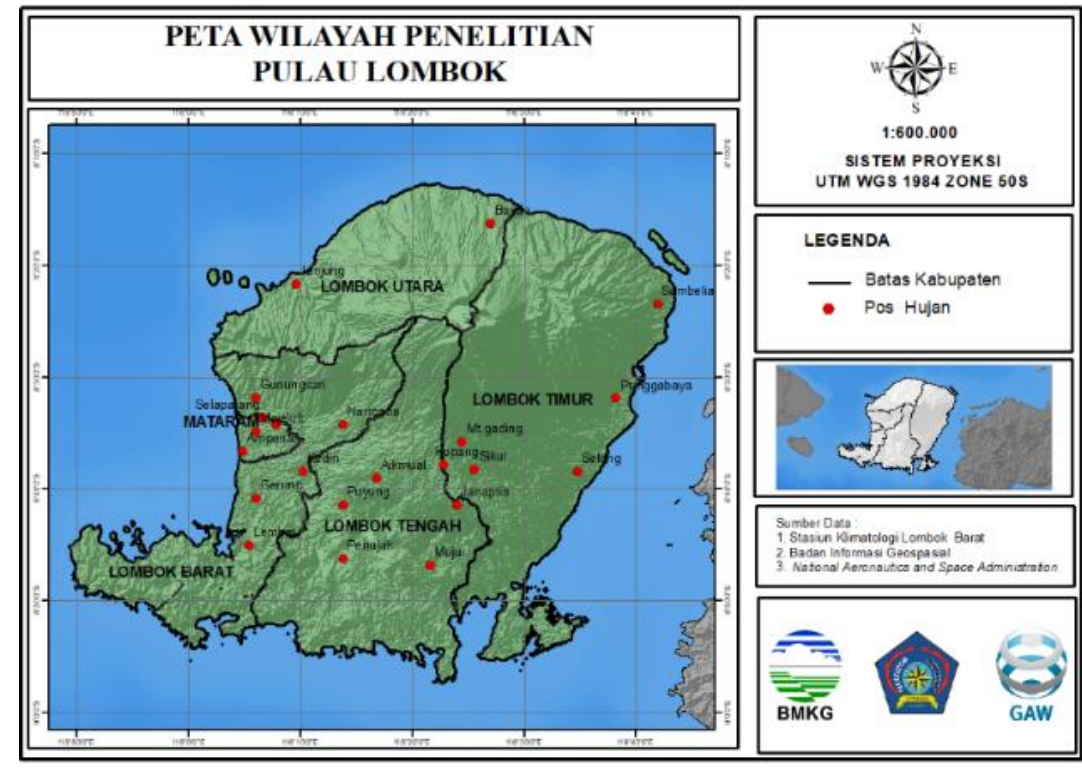

Gambar 1. Wilayah penelitian 
Data yang digunakan antara lain data observasi curah hujan, suhu maksimum, suhu minimum, lintang, elevasi, penginderaan jauh Normalized Differences Vegetation Index (NDVI) Satelit Modis-Terra dengan resolusi $0,05^{\circ}$ dan model FLDAS kecepatan angin dengan resolusi $0,5^{\circ}$ yang diperoleh dengan mengakses halaman website

Giovanni

(https://giovanni.gsfc.nasa.gov/giovanni/), serta lama penyinaran matahari yang diakses dari halaman website Culture on Demand (https://orchidculture.com/COD/daylength.html).

Semua data tersebut merupakan data dengan skala bulanan tahun 2001-2018 di 22 titik pos hujan wilayah Lombok.

Meteode penelitian dimulai dengan melakukan pendugaan suhu maksimum dan minimum di 22 titik pos hujan lainnya dengan menggunakan data suhu maksimum dan minimum Stasiun Klimatologi Lombok Barat sebagai referensi. Perhitungan suhu tersebut menggunakan formula yang ditunjukkan pada persamaan (1) (Braak, 1929)

$$
T_{h}=T_{h 0}-\left(\frac{0,6}{100} h\right)
$$

dengan $T_{h}$ adalah suhu maksimum/minimum pos hujan $\left({ }^{\circ} \mathrm{C}\right), T_{h 0}$ adalah suhu maksimum/minimum stasiun referensi $\left({ }^{\circ} \mathrm{C}\right)$, dan $h$ adalah selisih ketinggian pos hujan $(\mathrm{m})$.

Hasil pendugaan suhu maksimum dan minimum menggunakan rumus (1) diasumsikan sebagai data observasi.

Selanjutnya, melakukan penghitungan SPEI menggunakan curah hujan sebagai input presipitasi $(P)$ dan evapotrasnspirasi potensial (PET) untuk bulan $i$ disajikan dengan persamaan (2) berikut ini.

$$
D_{i}=P_{i}-P E T_{i}
$$

Nilai $D_{i}$ dijumlahkan berdasarkan skala waktu dengan persamaan (3) berikut ini.

$$
D_{n}^{k}=\sum_{i=0}^{k-1} P_{n-i}-P E T_{n-i}
$$

dengan $k$ adalah bulan dan $n$ adalah penjumlahan bulan.

Nilai PET didapatkan dengan perhitungan evapotranspirasi potensial Penman - Monteith (Monteith, 1965) menggunakan persamaan (4) berikut ini.

$$
E T_{0}=\frac{0,408 \Delta+\gamma \frac{900}{(T+273)} U_{2}\left(e_{s}-e_{a}\right)}{\Delta+\gamma\left(1+0,34 U_{2}\right)}
$$

dengan $E T_{0}$ adalah evapotranspirasi tanaman acuan (mm/hari), $R_{n}$ adalah radiasi matahari netto diatas permukaan tanaman ( $\mathrm{MJ} / \mathrm{m}^{2} /$ hari), $T$ adalah suhu udara rata - rata $\left({ }^{\circ} \mathrm{C}\right), U_{2}$ adalah kecepatan angin pada ketinggian $2 \mathrm{~m}$ diatas permukaan tanah $(\mathrm{m} / \mathrm{s}), e_{s}$ adalah tekanan uap air jenuh $(\mathrm{kPa}), e_{a}$ adalah tekanan uap air aktual $(\mathrm{kPa}), \Delta$ adalah kemiringan kurva tekanan uap air terhadap suhu $\left(\mathrm{kPa} /{ }^{\circ} \mathrm{C}\right)$, dan $\gamma$ adalah konstanta psikometrik $\left(\mathrm{kPa} /{ }^{\circ} \mathrm{C}\right)$.
Perhitungan PET dan SPEI dilakukan menggunakan package SPEI pada aplikasi $R$ Statistic. Nilai SPEI dihitung dalam skala 1 bulanan $\left(\mathrm{SPEl}_{1}\right), 3$ bulanan $\left(\mathrm{SPEl}_{3}\right), 6$ bulanan (SPEl 6 ), dan 12 bulanan (SPEl 12 ).

Kemudian, menghitung nilai SVI sebagai indeks kekeringan vegetasi atau agrikultultural (Peters, et al., 2002). Kondisi vegetasi wilayah Lombok didominasi oleh tanaman pertanian dan holtikultura (BPS NTB, 2019), sehingga sangat bergantung pada kondisi curah hujan. Penghitungan nilai SVI dilakukan dengan cara menstandardisasikan penyimpangan NDVI dari kondisi normal atau rata-ratanya, yang disebut dengan Z-Score. Rumus perhitungan Z-Score disajikan pada persamaan (5) berikut ini.

$$
Z_{x y}=\frac{\left(V I_{x y}-\mu_{x}\right)}{\sigma_{x}}
$$

dengan $Z_{x y}$ adalah $Z$-Score pada bulan $\mathrm{x}$ dan tahun $\mathrm{y}, V I_{x y}$ adalah NDVI pada bulan $\mathrm{x}$ dan tahun $\mathrm{y}, \mu_{x}$ adalah rata-rata NDVI bulan $\mathrm{x}$ dan $\mathrm{n}$ tahun, dan $\sigma_{x}$ adalah standar deviasi NDVI bulan $\mathrm{x}$ dan $\mathrm{n}$ tahun.

Keringan vegetasi (SVI) ini dibagi menjadi 2 , yaitu lag 0 dan lag +1 dengan maksud untuk mengetahui kejadian kekeringan meteorologis berpengaruh pada kondisi vegetasi saat itu juga atau satu bulan setelah kejadian kekeringan.

Hasil perhitungan SPEI dan SVI kemudian dikorelasikan menggunakan Korelasi Pearson karena kedua indeks berupa data tunggal (Sudjana, 1996). Rumus dan interpretasi nilai koefisien korelasi yang digunakan oleh penulis disajikan pada persamaan (6) dan Tabel 1 berikut ini.

$$
r_{x y}=\frac{n \sum X Y-\left(\sum X\right)\left(\sum Y\right)}{\left.\left(\sqrt{n \sum\left(X^{2}\right)}\right)-\left(\sum X\right)^{2}\right)\left(n \sum\left(Y^{2}\right)-\left(\sum Y\right)^{2}\right)}
$$

dengan $r_{x y}$ adalah korelasi antara variabel $X$ dan $Y, n$ adalah banyak data, $X$ adalah variabel satu (SPEI), dan $Y$ variabel dua (SVI).

Tabel 1. Interpretasi nilai koefisien korelasi Sumber: Wijayanto, 2008

\begin{tabular}{|c|c|}
\hline Nilai $\mathbf{r}$ & Interpretasi \\
\hline 0 & Tidak berkolerasi \\
\hline $0,01-0,20$ & Korelasi sangat rendah \\
\hline $0,21-0,40$ & Rendah \\
\hline $0,41-0,60$ & Cukup kuat \\
\hline $0,61-0,80$ & Kuat \\
\hline $0,81-0,99$ & Sangat Kuat \\
\hline 1 & Berkorelasi sempurna \\
\hline
\end{tabular}

Kemudian untuk menguji keakuratan koefisien korelasi dilakuan dengan menggunakan uji signifikansi dengan metode uji-t. Adapun uji signifikansi dengan metode uji-t disajikan dengan formula berikut ini (Sudjana, 1996), 


$$
t_{\text {hitung }}=\frac{r \sqrt{n-2}}{\sqrt{1-r^{2}}}
$$

dengan $t_{\text {hitung }}$ adalah koefisien signifikansi, $r$ adalah koefisien Korelasi Pearson, dan $n$ adalah banyaknya data.

Selanjutnya untuk menentukan $t_{\text {tabel }}$ memerlukan tingkat signifikansi dan degree of freedom $(d f)$ yang ditentukan dari jumlah data $(n)$ dikurangi jumlah variabel $(k)$. Kriteria signifikansi berdasarkan $t_{\text {hitung }}$ dan $t_{\text {tabel }}$ disajikan pada persamaan (8) berikut ini,

$$
\begin{gathered}
t_{\text {hitung }}>t_{\text {tabel }}=H_{0} \text { ditolak } \\
t_{\text {hitung }}<t_{\text {tabel }}=H_{0} \text { diterima }
\end{gathered}
$$

parameter $H_{0}$ berarti hipotesis awal yang menyatakan tidak ada hubungan diantara SPEI dengan SVI. Pada penelitian ini, penulis menggunakan taraf signifikansi 95\%. Hasil korelasi SPEI dengan SVI tersebut kemudian dipetakan menggunakan software ArcGIS 10.3 untuk mengetahui sebaran korelasi secara spasial.

\section{HASIL DAN PEMBAHASAN}

\subsection{Analisis SPEI 1 dengan SVI}

Nilai korelasi SPEl 1 dengan SVI semuanya bernilai positif atau searah, baik untuk $\mathrm{SVI}_{0}$ maupun $\mathrm{SVI}_{+1}$. Korelasi bernilai positif dan searah ini menggambarkan bahwa apabila terjadi kekeringan meteorologis maka akan berdampak pada kekeringan pertanian di wilayah Lombok. Rata-rata korelasi untuk SVI bernilai rendah dan $\mathrm{SVI}_{+1}$ cukup kuat. Korelasi tertinggi dan terendah secara berurutan untuk $\mathrm{SVI}_{0}$ yaitu 0,43 dan 0,23 yang terjadi di Kediri dan Sambelia. Nilai $p$-value kedua wilayah ini masing-masing 0,000, yang berarti terjadi hubungan yang nyata dan signifikan. Sedangkan untuk nilai korelasi tertinggi untuk $\mathrm{SVI}_{+1}$ adalah 0,60 yang terjadi di Penujak dan terendah sebesar 0,26 yang terjadi di Sambelia. SPEl ${ }_{1}$ wilayah ini juga berkorelasi signifikan dengan $\mathrm{SVI}_{+1}$ karena memiliki $p$-value sebesar 0,000. Secara detail nilai korelasi $\mathrm{SPEl}_{1}$ dengan SVI disajikan pada Tabel 2 di bawah ini.

Tabel 2. Nilai korelasi SPEl 1 dengan SVI

\begin{tabular}{|c|l|c|c|}
\hline No & Pos Hujan & SVI $_{\mathbf{0}}$ & SVL $_{\mathbf{1}}$ \\
\hline 1 & Lembar & 0,38 & 0,49 \\
\hline 2 & Puyung & 0,43 & 0,49 \\
\hline 3 & Penujak & 0,39 & 0,60 \\
\hline 4 & Aikmual & 0,39 & 0,49 \\
\hline 5 & Narmada & 0,30 & 0,40 \\
\hline 6 & Kediri & 0,43 & 0,46 \\
\hline 7 & Majeluk & 0,42 & 0,46 \\
\hline 8 & Gunungsari & 0,32 & 0,40 \\
\hline 9 & Gerung & 0,38 & 0,44 \\
\hline 10 & Tanjung & 0,41 & 0,40 \\
\hline 11 & Bayan & 0,37 & 0,41 \\
\hline 12 & Mt. Gading & 0,39 & 0,44 \\
\hline 13 & Kopang & 0,34 & 0,45 \\
\hline 14 & Janapria & 0,38 & 0,46 \\
\hline 15 & Mujur & 0,28 & 0,35 \\
\hline 16 & Ampenan & 0,29 & 0,37 \\
\hline 17 & Cakranegara & 0,36 & 0,48 \\
\hline 18 & Sembelia & 0,23 & 0,26 \\
\hline 19 & Selong & 0,28 & 0,32 \\
\hline 20 & Pringgabaya & 0,26 & 0,29 \\
\hline 21 & Sikur & 0,35 & 0,39 \\
\hline 22 & Selaparang & 0,23 & 0,34 \\
\hline & MAX & 0,43 & 0,60 \\
\hline & MIN & 0,23 & 0,26 \\
\hline & RERATA & 0,34 & 0,42 \\
\hline
\end{tabular}

Nilai korelasi $\mathrm{SPEl}_{1}$ dengan $\mathrm{SVI}_{0}$ didominasi kategori rendah, tersebar di sebagian besar Pulau Lombok dan disajikan pada Gambar 2 berikut ini.

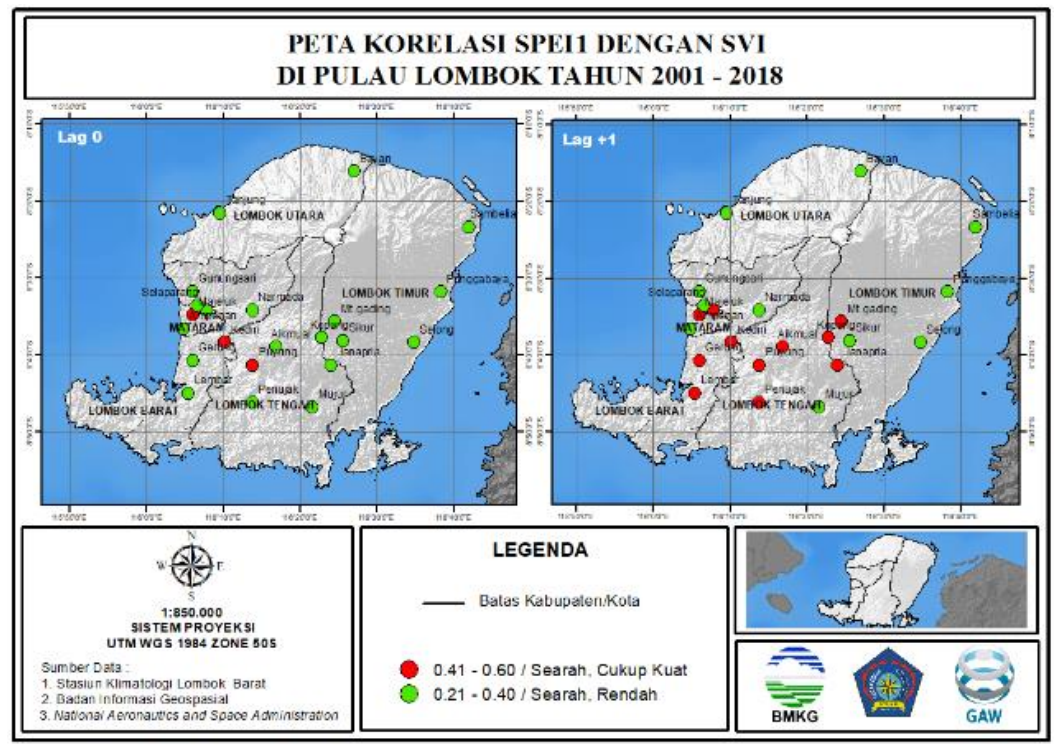

Gambar 2. Korelasi SPEl 1 dengan SVI di Pulau Lombok tahun 2001-2018 
Terdapat 3 pos hujan yang berkorelasi cukup kuat (Gambar 2). Tiga pos hujan ini tersebar masing-masing satu pos hujan di Kabupaten Lombok Tengah, Lombok Barat, dan Kota Mataram. Sedangkan untuk $\mathrm{SVI}_{+1}$, masih didominasi pos hujan dengan korelasi rendah untuk setiap kabupatennya, namun lebih banyak terdapat pos hujan dengan korelasi cukup kuat jika dibandingkan dengan SVIo. Pos hujan dengan korelasi cukup kuat dengan $\mathrm{SVI}_{+1}$ ini terdapat di tengah-tengah wilayah Lombok dan tersebar hampir di seluruh kabupaten/kota Lombok (kecuali Kabupaten Lombok Utara).

Hasil korelasi SPEI ${ }_{1}$ dengan SVI memiliki nilai yang lebih tinggi untuk $S \mathrm{VI}_{+1}$. Hal ini menunjukkan jika kekeringan meteorologis yang terjadi di wilayah Lombok tidak langsung memengaruhi kondisi vegetasi saat itu juga. Terdapat lag time 1 bulan sampai kekeringan meteorologisnya memengaruhi kondisi vegetasi wilayah Lombok, yang dalam hal ini yaitu kekeringan pertanian. Kondisi ini dijelaskan dalam penelitian Zuo, et al. (2019) dan Ezzine, et al. (2014) bahwa ketika hujan tidak turun dan terjadi defisit curah hujan, tumbuhan masih dapat menggunakan cadangan air yang terdapat di dalam tanah, serta menurut Maina (2018), bahwa lag time ini terjadi karena tumbuhan masih mempunyai cadangan energi dalam tubuhnya untuk berkembang. Intensitas dan durasi kekeringan meteorologis tentunya berpengaruh terhadap kondisi vegetasi dan ketersediaan air. Apabila intensitas curah hujan sedikit dan berlangsung dalam waktu yang lama, maka ketersedian air juga menipis hingga habis, dan kebutuhan konsumsi air untuk tanaman tidak lagi dapat terpenuhi. Hal inilah yang memicu terjadinya kekeringan agrikultural sebagai dampak dari kekeringan meteorologis. Hal ini sejalan dengan penelitian Adhyani et al. (2017) yang menyatakan terjadinya kekeringan adalah proses yang berlangsung dengan periode tertentu serta dapat berdampak secara luas dan parah, termasuk kondisi vetetasi.

\subsection{Analisis $\mathrm{SPEI}_{3}$ dengan SVI}

Hasil analisis menunjukkan bahwa semua pos hujan untuk semua indeks berkorelasi positif dan searah. Secara detail nilai korelasi $\mathrm{SPEl}_{3}$ dengan SVI disajikan pada Tabel 3 di bawah ini.

Tabel 3. Nilai korelasi $\mathrm{SPEl}_{3}$ dengan SVI

\begin{tabular}{|c|l|c|c|}
\hline No & Pos Hujan & SVI $_{\mathbf{0}}$ & $\mathbf{S V L}_{\mathbf{1}}$ \\
\hline 1 & Lembar & 0,38 & 0,49 \\
\hline 2 & Puyung & 0,43 & 0,49 \\
\hline 3 & Penujak & 0,39 & 0,60 \\
\hline 4 & Aikmual & 0,39 & 0,49 \\
\hline 5 & Narmada & 0,30 & 0,40 \\
\hline 6 & Kediri & 0,43 & 0,46 \\
\hline 7 & Majeluk & 0,42 & 0,46 \\
\hline 8 & Gunungsari & 0,32 & 0,40 \\
\hline 9 & Gerung & 0,38 & 0,44 \\
\hline 10 & Tanjung & 0,41 & 0,40 \\
\hline 11 & Bayan & 0,37 & 0,41 \\
\hline 12 & Mt. Gading & 0,39 & 0,44 \\
\hline 13 & Kopang & 0,34 & 0,45 \\
\hline 14 & Janapria & 0,38 & 0,46 \\
\hline 15 & Mujur & 0,28 & 0,35 \\
\hline 16 & Ampenan & 0,29 & 0,37 \\
\hline 17 & Cakranegara & 0,36 & 0,48 \\
\hline 18 & Sembelia & 0,23 & 0,26 \\
\hline 19 & Selong & 0,28 & 0,32 \\
\hline 20 & Pringgabaya & 0,26 & 0,29 \\
\hline 21 & Sikur & 0,35 & 0,39 \\
\hline 22 & Selaparang & 0,23 & 0,34 \\
\hline \multicolumn{2}{|c|}{ MAX } & 0,43 & 0,60 \\
\hline \multicolumn{2}{|c|}{ MIN } & 0,23 & 0,26 \\
\hline \multicolumn{2}{|c|}{ RERATA } & 0,34 & 0,42 \\
\hline
\end{tabular}

Sebaran nilai korelasi $\mathrm{SPEI}_{3}$ dengan SVI untuk setiap pos hujan di wilayah Lombok penulis sajikan pada Gambar 3.

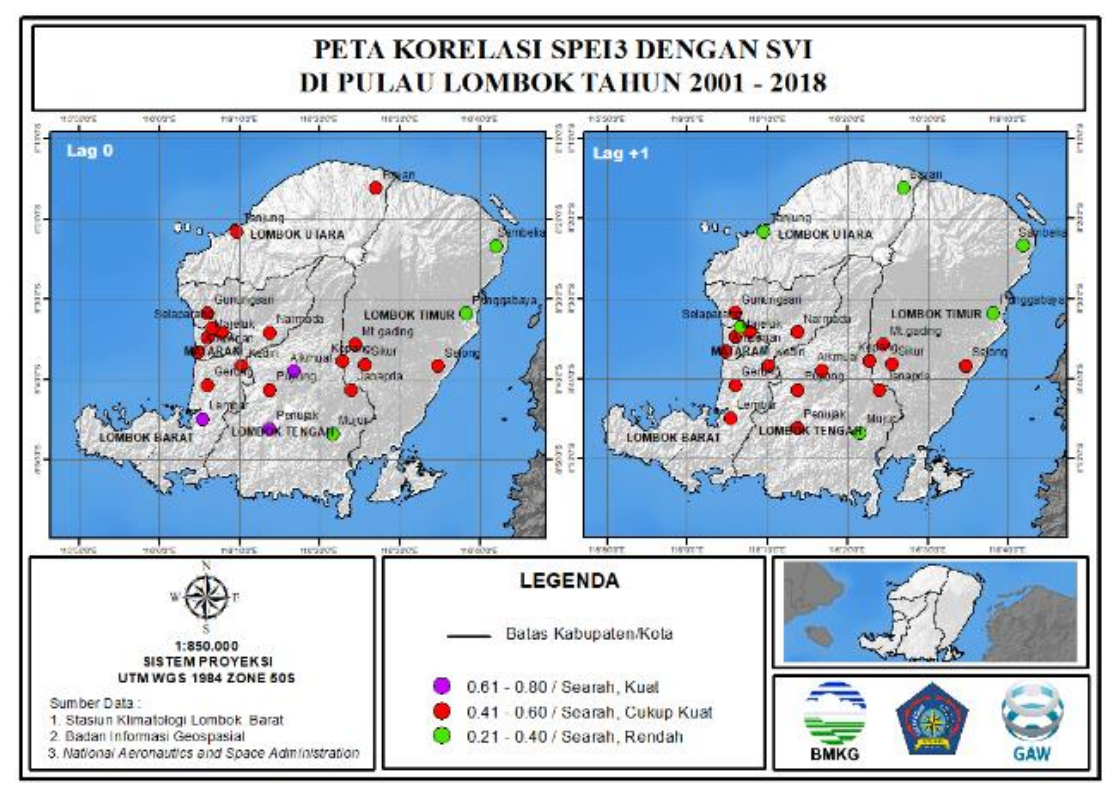

Gambar 3. Korelasi $\mathrm{SPEI}_{3}$ dengan SVI di Pulau Lombok tahun 2001-2018 


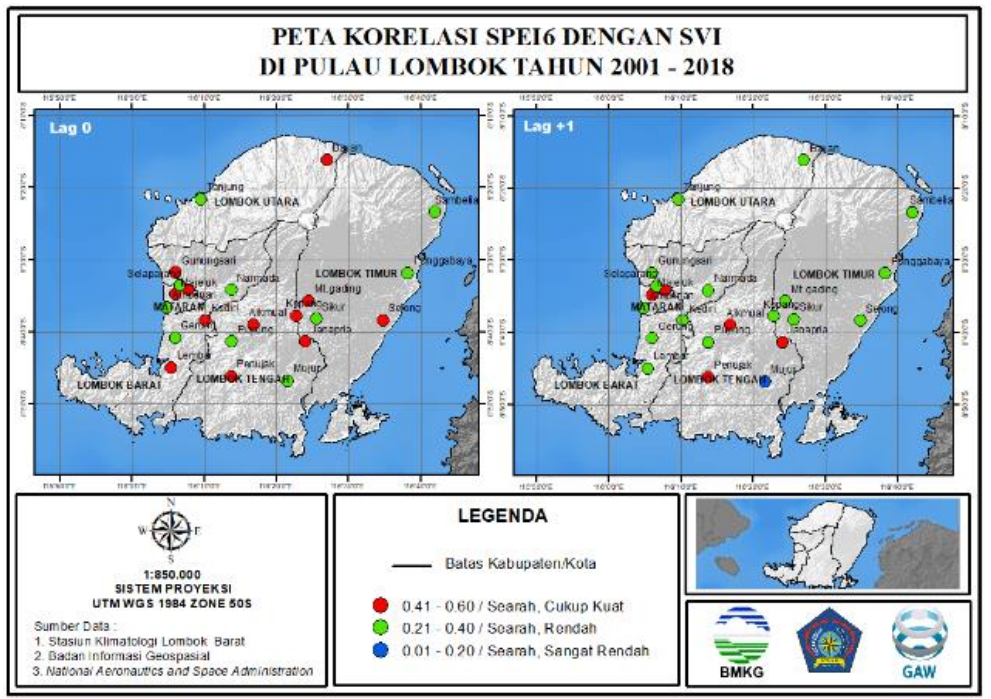

Gambar 4. Korelasi SPEI 6 dengan SVI di Pulau Lombok tahun 2001-2018

Gambar 3 menunjukkan bahwa korelasi $\mathrm{SPEl}_{3}$ paling tinggi dengan $\mathrm{SVI}_{0}$ terdapat di Aikmual sebesar 0,78 dengan $p$-value 0,000 . Sedangkan terendah sebesar 0,34 di Sambelia dengan $p$-value 0,000 . $\mathrm{SPEl}_{3}$ yang berkaitan paling tinggi dengan $\mathrm{SVI}_{+1}$ terdapat di Cakranegara dengan nilai korelasi sebesar 0,59 dan paling rendah di Sambelia sebesar 0,30. Nilai $p$-value secara berurutan yaitu 0,000 dan 0,000 . Dengan demikian, setiap pos hujan yang telah disebutkan di atas berkorelasi secara signifikan dengan $\mathrm{SPEl}_{3}$ karena bernilai kurang dari 0,05.

Selain itu, Gambar 3 menunjukkan bahwa sebaran nilai korelasi pada pos hujan didominasi dengan kategori cukup kuat untuk setiap kabupaten/kota di wilayah Lombok, baik untuk $S \mathrm{SI}_{0}$ maupun $\mathrm{SVI}_{+1}$. Nilai korelasi $S \mathrm{SI}_{0}$ yang tertinggi adalah kategori kuat yang terdapat di 3 pos hujan dengan rincian 2 pos hujan di Kabupaten Lombok Tengah dan 1 pos hujan di Kabupaten Lombok Barat.

Sedangkan untuk $S \mathrm{SI}_{+1}$, sebaran pos hujan yang memiliki korelasi cukup kuat berada di tengah-tengah Pulau Lombok dan tersebar di hampir seluruh kabupaten/kota, kecuali Kabupaten Lombok Utara. Pos hujan lainnya yang berkorelasi rendah terdapat di pesisir barat, utara, dan timur wilayah Lombok. Kondisi kekeringan meteorologis 3 bulanan ini langsung berpengaruh terhadap kondisi vegetasi atau kekeringan agrikultural di wilayah Lombok. Hal ini dibuktikan dengan cukup banyak pos hujan yang berkorelasi cukup kuat dengan mampu memberikan indikator kondisi vegetasi yang hampir real-time dalam wilayah kekeringan dan khususnya wilayah dengan kondisi kekeringan dengan tingkatan yang bervariasi. indeks SVIo. Hasil ini selaras dengan penelitian Peters et al. (2002) yang menyatakan bahwa SVI Wang et al. (2016) menyatakan jika kondisi curah hujan, geografi, dan demografi suatu wilayah menjadi faktor yang memengaruhi kejadian kekeringan. Hal ini memberikan pemahaman terkait sebaran korelasi katagori cukup kuat hingga kuat yang terdapat di tengahtengah Pulau Lombok yang merupakan wilayah dengan curah hujan rendah dan didominasi lahan kering. Selain itu, pusat kegiatan manusia yang berada di tengah kota dapat mengurangi kondisi air tanah yang ada

\subsection{Analisis SPEI 6 dengan SVI}

Korelasi SPEl6 dengan SVI menunjukkan hubungan yang positif dan searah untuk semua pos hujan. Secara detail nilai korelasi $\mathrm{SPEl}_{6}$ dengan SVI disajikan pada Tabel 4 di bawah ini.

Tabel 4. Nilai Korelasi SPEI 6 dengan SVI

\begin{tabular}{|c|c|c|c|}
\hline No & Pos Hujan & SVI & $\mathrm{SVL}_{1}$ \\
\hline 1 & Lembar & 0,61 & 0,54 \\
\hline 2 & Puyung & 0,57 & 0,48 \\
\hline 3 & Penujak & 0,62 & 0,53 \\
\hline 4 & Aikmual & 0,78 & 0,58 \\
\hline 5 & Narmada & 0,48 & 0,45 \\
\hline 6 & Kediri & 0,60 & 0,53 \\
\hline 7 & Majeluk & 0,58 & 0,54 \\
\hline 8 & Gunungsari & 0,50 & 0,47 \\
\hline 9 & Gerung & 0,46 & 0,42 \\
\hline 10 & Tanjung & 0,46 & 0,39 \\
\hline 11 & Bayan & 0,48 & 0,41 \\
\hline 12 & Mt. Gading & 0,55 & 0,51 \\
\hline 13 & Kopang & 0,52 & 0,48 \\
\hline 14 & Janapria & 0,60 & 0,55 \\
\hline 15 & Mujur & 0,40 & 0,31 \\
\hline 16 & Ampenan & 0,46 & 0,41 \\
\hline 17 & Cakranegara & 0,59 & 0,59 \\
\hline 18 & Sembelia & 0,34 & 0,30 \\
\hline 19 & Selong & 0,45 & 0,43 \\
\hline 20 & Pringgabaya & 0,37 & 0,35 \\
\hline 21 & Sikur & 0,47 & 0,41 \\
\hline 22 & Selaparang & 0,42 & 0,41 \\
\hline \multicolumn{2}{|r|}{ MAX } & 0,78 & 0,59 \\
\hline \multicolumn{2}{|r|}{ MIN } & 0,35 & 0,30 \\
\hline \multicolumn{2}{|r|}{ RERATA } & 0,51 & 0,46 \\
\hline
\end{tabular}




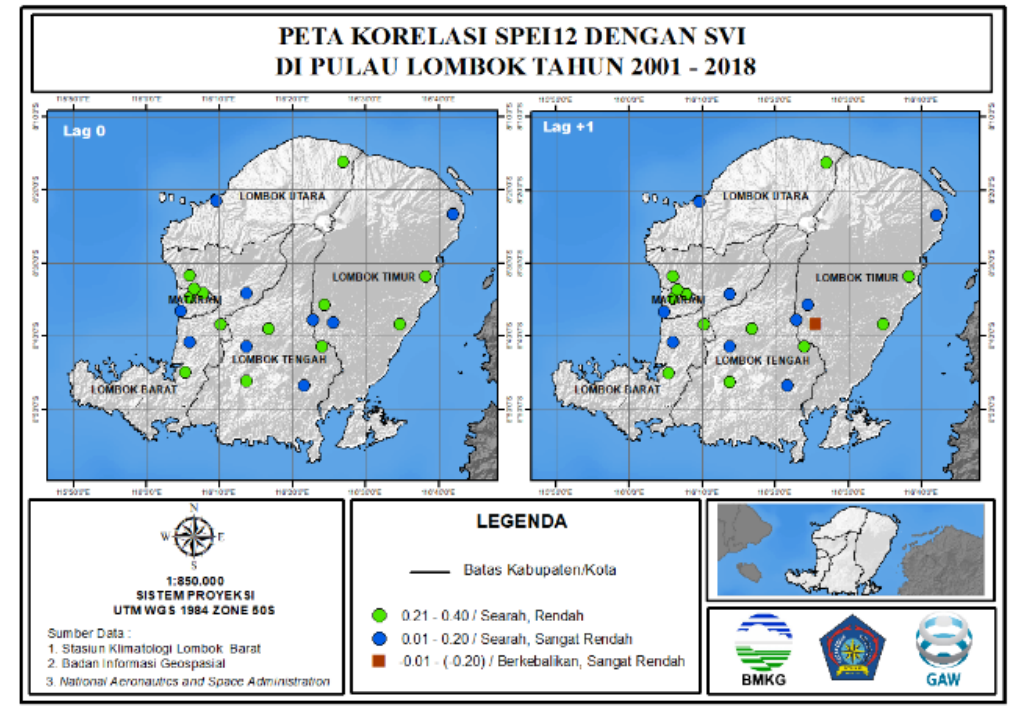

Gambar 5. Korelasi SPEl ${ }_{12}$ dengan SVI di Pulau Lombok tahun 2001-2018

Tabel 4 menunjukkan bahwa nilai korelasi tertinggi dengan $\mathrm{SVI}_{0}$ terjadi di Aikmual dengan korelasi sebesar 0,55 dengan $p$-value sebesar 0,000 . Sedangakan terendah bernilai $0,22 \mathrm{di}$ Mujur dengan $p$-value sebesar 0,000 . Pos hujan yang memiliki nilai korelasi $\mathrm{SVI}_{+1}$ tertinggi adalah Cakranegara sebesar 0,46 dan terendah terdapat di Mujur sebesar 0,15. Nilai $p$-value untuk keduanya secara berurutan yaitu 0,000 dan 0,027 . Dengan nilai $p$-value kurang dari 0,05 untuk setiap pos hujan yang telah disebutkan, dapat dinyatakan bahwa korelasi terjadi secara nyata dan signifikan.

Sebaran nilai korelasi SPEI ${ }_{6}$ dengan SVI untuk setiap pos hujan di wilayah Lombok penulis sajikan pada Gambar 4. Gambar tersebut menunjukkan jika korelasi lebih tinggi terjadi untuk $\mathrm{SVI}_{0}$. Hal ini dibuktikan dengan pos hujan dengan kategori korelasi cukup kuat lebih mendominasi di wilayah Lombok untuk SVIo dibandingkan dengan $\mathrm{SVI}_{+1}$ yang didominasi oleh korelasi rendah. Kategori korelasi cukup kuat untuk kedua indeks ini tersebar di tengah-tengah Pulau Lombok. Korelasi rendah yang mendominasi pada $\mathrm{SVI}_{+1}$ tersebar di seluruh kabupaten/kota di Lombok. Sedangkan untuk kategori cukup kuat, hanya terdapat di 3 pos hujan di Kabupaten Lombok Tengah dan 2 pos hujan di Kota Mataram dari total 22 pos hujan utama yang digunakan dalam penelitian ini. Kekeringan agrikultural $\mathrm{SVI}_{0}$ di wilayah Lombok juga dipengaruhi oleh kekeringan meteorologis 6 bulanan yang ditunjukkan dengan nilai korelasi yang lebih besar untuk SVIo dibandingkan dengan $\mathrm{SVI}_{+1}$. Hal ini sejalan dengan penelitian yang dilakukan oleh Maina (2018) yang menyatakan SPEI jangka panjang lebih berkorelasi tinggi dengan SVI jangka pendek serta memiliki $p$-value kurang dari 0,05.

\subsection{Analisis SPEl 12 dengan SVI}

Korelasi SPEI ${ }_{12}$ dengan SVI secara umum memiliki kategori rendah hingga sangat rendah. Korelasi $\mathrm{SPEl}_{12}$ dengan $\mathrm{SVI}_{0}$ tertinggi terjadi di
Penujak sebesar 0,38 dengan $p$-value 0,000 , sedangkan terendah terjadi di Sikur sebesar 0,04 dengan $p$-value 0,522 . Nilai korelasi curah hujan dengan $\mathrm{SVI}_{+1}$ tertinggi sebesar 0,33 yang terjadi di Penujak dengan $p$-value 0,000.

Tabel 5. Nilai Korelasi SPEl 12 dengan SVI

\begin{tabular}{|c|l|c|c|}
\hline No & Pos Hujan & SVI $_{\mathbf{0}}$ & SVL $_{\mathbf{1}}$ \\
\hline 1 & Lembar & 0,50 & 0,41 \\
\hline 2 & Puyung & 0,40 & 0,31 \\
\hline 3 & Penujak & 0,52 & 0,41 \\
\hline 4 & Aikmual & 0,55 & 0,46 \\
\hline 5 & Narmada & 0,33 & 0,23 \\
\hline 6 & Kediri & 0,48 & 0,39 \\
\hline 7 & Majeluk & 0,52 & 0,46 \\
\hline 8 & Gunungsari & 0,41 & 0,37 \\
\hline 9 & Gerung & 0,30 & 0,24 \\
\hline 10 & Tanjung & 0,31 & 0,24 \\
\hline 11 & Bayan & 0,42 & 0,37 \\
\hline 12 & Mt. Gading & 0,46 & 0,34 \\
\hline 13 & Kopang & 0,42 & 0,31 \\
\hline 14 & Janapria & 0,54 & 0,44 \\
\hline 15 & Mujur & 0,22 & 0,15 \\
\hline 16 & Ampenan & 0,37 & 0,34 \\
\hline 17 & Cakranegara & 0,51 & 0,46 \\
\hline 18 & Sembelia & 0,28 & 0,22 \\
\hline 19 & Selong & 0,45 & 0,41 \\
\hline 20 & Pringgabaya & 0,35 & 0,31 \\
\hline 21 & Sikur & 0,36 & 0,24 \\
\hline 22 & Selaparang & 0,39 & 0,36 \\
\hline & MAX & 0,55 & 0,46 \\
\hline & MIN & 0,22 & 0,15 \\
\hline & RERATA & 0,41 & 0,34 \\
\hline
\end{tabular}

Sebaran nilai korelasi SPEl ${ }_{12}$ dengan SVI untuk setiap pos hujan di wilayah Lombok penulis sajikan pada Gambar 5. Secara umum, Gambar 5 menunjukkan bahwa $\mathrm{SVI}_{0}$ dan $\mathrm{SVI}_{+1}$ didominasi oleh korelasi dengan kategori rendah yang tersebar di setiap kabupaten/kota wilayah Lombok. Pola persebaran kategori korelasi untuk setiap pos hujan di seluruh wilayah 
kabupaten/kota hampir sama. Perbedaan yang terlihat adalah untuk $S V I_{0}$ semua pos hujan bernilai positif, sedangkan untuk $\mathrm{SVI}_{+1}$ terdapat satu pos hujan dengan nilai negatif sangat rendah di wilayah Kabupaten Lombok Timur. Nilai korelasi yang rendah ini dipengaruhi oleh jenis tanaman di wilayah Lombok yang didominasi oleh tanaman pertanian dan holtikultura, dimana tanaman ini memiliki siklus hidup semusim, sehingga tidak relevan jika menggunakan indeks SPEI jangka panjang karena sudah melebihi satu siklus hidup tanaman tersebut. Seperti halnya penelitian yang dilakukan oleh Ji dan Peter (2003) menyatakan jika kekeringan jangka panjang dapat memengaruhi kondisi vegetasi secara langsung apabila sesuai dengan siklus hidup tanaman.

\section{KESIMPULAN}

Berdasarkan pengolahan dan analisis yang telah dilakukan, hubungan SPEI dengan SVI di berbagai titik pengamatan hujan di Pulau Lombok tahun 2001-2018 menunjukkan nilai dan tingkat yang bervariasi untuk setiap periode indeks kekeringan. Namun, hubungan yang lebih kuat terdapat di pos-pos hujan yang berada di tengahtengah Pulau Lombok. Hasil korelasi menunjukkan hubungan yang lebih kuat terjadi pada SVIo untuk periode SPEI jangka pendek hingga menengah.

Hasil korelasi SPEl $_{1}$ lebih tinggi berkorelasi dengan $\mathrm{SVI}_{+1}$, sedangkan SPEI untuk jangka waktu 3 bulanan, 6 bulanan, dan 12 bulanan berkorelasi tinggi dengan SVIo. Perbedaan ini diyakini sebagai perbedaan jangka waktu tanaman dalam merespon kondisi kebutuhannya. Kekeringan 1 bulanan masih dapat diadaptasi oleh tumbuhan dengan memanfaatkan kandungan air dan energi yang tersimpan dalam tanah serta tubuhnya. Namun ketika sudah mencapai 3 hingga 12 bulan, tanaman tidak lagi dapat bertahan, sehingga kekeringan jangka panjang akan langsung mempengaruhi kondisi vegetasi wilayah Lombok sehingga menyebakan kekeringan agrikultural.

Korelasi tertinggi terjadi pada $\mathrm{SPEl}_{3}$ dengan SVIo untuk setiap pos hujan, sedangkan terendah adalah korelasi $\mathrm{SPEl} \mathrm{I}_{12}$ dengan $\mathrm{SVI}_{+1}$. Hal ini menunjukkan jika SPEl lebih dapat digunakan untuk memantau kekeringan musiman atau 3 bulanan dibandingkan dengan kekeringan jangka panjang di wilayah Lombok. Selain itu, SPEI jangka panjang seperti SPEI 6, 9, dan 12 lebih cocok digunakan untuk mengetahui pengaruh terhadap ketersediaan air di bendungan atau penampungan air kapasitas besar. Berbagai hasil penelitian menunjukkan untuk tanaman lebih baik menggunakan SPEI dengan interval 3 bulanan.

Beberapa hal yang dapat dilakukan untuk melengkapi keterbatasan penelitian ini adalah lokasi penelitian sebaiknya memiliki sebaran pos hujan yang merata, sehingga setiap wilayah dapat terwakili. Selain itu, hasil perhitungan indeks kekeringan dapat diolah menjadi peta monitoring kekeringan secara historis dan menjadi bahan pertimbangan untuk penyusunan peta risiko kekeringan serta penyusunan strategi adaptasi dan mitigasi yang tepat.

\section{DAFTAR PUSTAKA}

Adhyani, N. L., June, T., \& Sopaheluwakan, A. (2017, March). Exposure to Drought: Duration, Severity and Intensity (Java, Bali and Nusa Tenggara). In IOP Conference Series: Earth and Environmental Science. Vol. 58, pp. 1755-1315. doi: 10.1088/17551315/58/1/012040

Badan Informasi Geospaisal. Peta Dinding Administrasi Provinsi Nusa Tenggara Barat http://www.big.go.id/. Diakses pada 10 Oktober 2019.

Badan Nasional Penanggulangan Bencana, (2015). Kajian Risiko Bencana Nusa Tenggara Barat 2016 - 2020. p. 51, Badan Nasional Penanggulangan Bencana, Jakarta.

Braak, C. (1929). The climate of the Netherlands Indies. Verhandelingen, 8, 1602.

Ezzine, H., Bouziane, A., \& Ouazar, D. (2014). Seasonal comparisons of meteorological and agricultural drought indices in Morocco using open short time-series data. International Journal of Applied Earth Observation and Geoinformation, 26, 3648. doi : 10.1016/j.jag.2013.05.005

Giovanni The Bridge Between Data and Science. Data. National Aeronautics and Space Administration. diakses dari https://giovanni.gsfc.nasa.gov/giovanni/

Ji, L., \& Peters, A. J. (2003). Assessing vegetation response to drought in the northern Great Plains using vegetation and drought indices. Remote Sensing of Environment, 87(1), 85-98. doi 10.1016/S0034-4257(03)00174-3

Maina, M. P. (2018) Drough Monitoring and Assessment Using Remote Sensing.

Monteith, J. L. (1965). Evaporation and environment. In Symposia of the society for experimental biology (Vol. 19, pp. 205-234). Cambridge University Press (CUP) Cambridge.

Park, J. S., Kim, K. T., \& Choi, Y. S. (2008, July). Application of vegetation condition index and standardized vegetation index for assessment of spring drought in South Korea. In IGARSS 2008-2008 IEEE International Geoscience and Remote Sensing Symposium (Vol. 3, pp. III-774). IEEE. doi : 10.1109/IGARSS.2008. 4779463

Peters, A. J., Walter-Shea, E. A., Ji, L., Vina, A., Hayes, M., \& Svoboda, M. D. (2002). Drought monitoring with NDVI-based 
standardized vegetation index. Photogrammetric engineering and remote sensing, 68(1), 71-75. doi : 0099$1112 / 02 / 6800-07$

Qi, S., Wang, C., Niu, Z., \& Liu, Z. (2004). SVI and $\mathrm{VCl}$ Based on NDVI Time-Series Dataset Used to Monitor Vegetation Growth Status and Its Response to Climate Variables [J]. Progress in Geography, 3. doi : 10.11820/dlkxjz.2004.03.012

Sudjana, N. (1996). Statistik Dasar. Tarsito. Bandung

Vicente-Serrano, S. M., Beguería, S., \& LópezMoreno, J. I. (2010). A multiscalar drought index sensitive to global warming: the standardized precipitation evapotranspiration index. Journal of climate, 23(7), 1696-1718. doi : 10.1175/2009JCLI2909.1

Wang, Z., Huang, Z., Li, J., Zhong, R., \& Huang, W. (2016). Assessing impacts of meteorological drought on vegetation at catchment scale in China based on SPEI and NDVI. Transactions of the Chinese Society of Agricultural Engineering, 32(14), 177-186. doi : 10.11975/j.issn.1002-6819. 2016.14.024

Wijayanto, A. (2008). Analisis Korelasi Product Moment Pearson.

Wilhite, D. A., \& Glantz, M. H. (1985). Understanding: the drought phenomenon: the role of definitions. Water international, 10(3), 111-120. doi : $10.1080 / 02508068508686328$

Zuo, D., Cai, S., Xu, Z., Peng, D., Kan, G., Sun, W., \& Yang, H. (2019). Assessment of meteorological and agricultural droughts using in-situ observations and remote sensing data. Agricultural Water Management, 222, 125-138. doi: 10.1016/j.agwat.2019.05.046 